\title{
Ecophysiological Studies of Vigna mungo L. Seedlings with Mercuric Chloride $\left(\mathrm{HgCl}_{2}\right)$ Stress
}

\author{
Mamata Mohapatra ${ }^{1 *}$, Prabha Ranjan Sethy ${ }^{2}$, Pragnya Routray ${ }^{2}$, Ramakrushna Mallick $^{2}$, Shivani Padhi ${ }^{2}$
}

${ }^{1}$ Assistant Professor, Khallikote Autonomous College, Berhampur-760001, Odisha, India

${ }^{2}$ P.G. Department of Botany and Biotechnology, Khallikote Autonomous College, Berhampur-760001, Odisha, India

DOI: $10.36347 /$ sajb.2021.v09i03.001 $\quad$ | Received: 26.02.2021 | Accepted: 11.03.2021 | Published: 16.03 .2021

*Corresponding author: Mamata Mohapatra

Abstract

Original Research Article

All heavy metals are potentially toxic at elevated concentrations. Effects of Mercuric Chloride on the morphological parameters such as germination percentage, root length, shoot length, number of leaves, fresh and dry biomass, pigments, Carbohydrate, Protein and Amino acids were analyzed during investigation on $10^{\text {th }}$ day seedlings of Vigna mungo L., All parameters exhibited reduced trend with increase in $\mathrm{HgCl}_{2}$ concentrations when compared to control plants. However, Protein content in shoot and root of the seedlings showed a different trend by increasing the content with the increase in heavy metal concentration. This indicates that, the seedlings are in the process of increase in tolerance to $\mathrm{HgCl}_{2}$ treatment. Metal toxicity affects crop yields, soil biomass and fertility.

Keywords: Mercuric Chloride $\left(\mathrm{HgCl}_{2}\right)$, Pulse, Vigna mungo, Pigment, Proteins, Aminoacids, Germination.

Copyright ( 12021 The Author(s): This is an open-access article distributed under the terms of the Creative Commons Attribution 4.0 International License (CC BY-NC 4.0) which permits unrestricted use, distribution, and reproduction in any medium for non-commercial use provided the original author and source are credited.

\section{INTRODUCTION}

Vigna mungo L. Or phaseolus mungo L. (black gram) is one of the most important pulse crops for human consumption in India. It is rich in protein, calcium, vitamins, magnesium, sodium, iron and fibers. It plays a vital role in improving the soil health through biological nitrogen fixation. It is also used for culinary preparation. Their yield is low and unstable due to water and other stresses during growth stage.

The green pods of Mung are eaten as vegetables and they are highly nutritious. It plays a vital role in improving the soil health through biological nitrogen fixation. It is largely used to make dal from whole grain or after splitting. Their yield is low and unstable due to water stress during growth stage. Heavy metals are integral components of ecosystems. The distinctiveness characteristics of heavy metals are poisoning and results in the inactivation of enzyme systems.

\section{Toxicity to Heavy Metals}

All heavy metals are potentially toxic at elevated concentrations. Exposure to heavy metals has been linked with developmental retardation, various cancers, kidney damage, and even death in some instances. Exposure to high levels of mercury and lead has also been associated with the development of autoimmunity, which can lead to the development of diseases like rheumatoid arthritis and diseases of the circulatory and nervous systems. Metal toxicity affects crop yields, soil biomass and fertility. Heavy metal toxicity is one of the foremost and current concerns for environmental health and potentially dangerous due to bioaccumulation through food chains.

The most common heavy metal contaminants are Lead ( $\mathrm{Pb}$ ), Cadmium (Cd), Mercury (Hg), Chromium $(\mathrm{Cr})$, Copper (CU), Nickel (Ni), and Zinc (Zn). All heavy metals are potentially toxic at elevated concentrations. The uptake of overload concentrations of heavy metals reduces the plant growth. This alteration in the plant growth is correlated with disruptions of physiological and cytological processes in plant cells and by this way the process of respiration, photosynthesis and mitotic activities are greatly affected by toxic effects of heavy metals.

\section{Mercury and its sources}

Mercury is a typical toxic trace metal pollutant. Bioaccumulation of $\mathrm{Hg}$ in plants and its entry into the food chain resulting in long term health hazard is of major concern. The steady release of mercury into the environment has resulted in current levels that are 3-6 times higher than the estimated levels in pre-industrial era atmosphere. 
Anthropogenic sources of $\mathrm{Hg}$ can be attributed as combustion of fossil fuels, wood, industrial wastes and effluents, sewage sludge and crematories, mining [1, 2]. high temperature processes, e.g. smelting, cement and lime production, Manufacturing/commercial activities: e.g. metal processing, gold extraction, $\mathrm{Hg}$ mining, chlor-alkali plants, chemical and instrument industry, agriculture application [3], landfills, seed dressing (fungicides), incineration of coal, other sources like cosmetics, dental fillings, preservatives, medical and laboratory wastes are the causes of mercury pollution. The $\mathrm{Hg}$ accumulated in vegetation may enter the human diet directly or through fish, birds and livestock. Moreover, the soil vegetation exchange of $\mathrm{Hg}$ gives a possibility to remove $\mathrm{Hg}$ from contaminated soil by plant uptake.

\section{Plant Interaction with mercury}

Plants are capable of extracting a variety of metal ions from their growth substrates, including $\mathrm{Hg}$. Many studies have showed that plant roots accumulate $\mathrm{Hg}$ when they were exposed to $\mathrm{Hg}$-contaminated soils [4]. Laboratory Studies showed that plant roots absorbed $\mathrm{Hg}$ from solution and roots accumulated much greater amount of $\mathrm{Hg}$ than shoots. Both field and laboratory studies have demonstrated that plants accumulate more $\mathrm{Hg}$ when it is introduced in organic form than in inorganic form.

Present investigation is aimed to study Mercuric Chloride action on plant growth characteristics of Black Gram (Vigna mungo L.) which is one of the most widely available pulse crops of India. In India it is grown over nearly 2.5 million hectares of land with a production about 0.7 million tones. This work is done for studying the effect of Mercuric chloride on Vigna mungo L. (in germination, seedling growth and other biochemical parameters).

\section{MATERIALS AND METHODS: SEED SELECTION}

The seeds of Vigna mungo L. were collected from OUAT, Ankushpur. Healthy seeds of uniform sizes were used.

\section{TEST CHEMICAL}

Mercuric Chloride $\left(\mathrm{Hg} \mathrm{Cl}_{2}\right)$ was used as the test chemical. First stock solution of $100 \mathrm{mg} / 1000 \mathrm{ml}$ was prepared by dissolving $100 \mathrm{mg}$ of test chemical in $1000 \mathrm{ml}$ of distilled water. Different concentrations of the metal were prepared by using distilled water as the solvent from the above stock solutions of different concentrations such as $(5 \mathrm{mg}, 15 \mathrm{mg}, 25 \mathrm{mg}, 35 \mathrm{mg} \&$ $45 \mathrm{mg} / \mathrm{L})$ solutions were prepared by proportional dilution with distilled water which is used for various treatments

\section{STUDY OF SEED VIABILITY}

The seeds were soaked with distilled water from 12 hrs-24 hrs. After scheduled periods of exposures, the seeds were washed with tap water, followed by distilled water and their viability was tested according to the procedure [5]. The result was expressed as $\%$ of mortality of seed grains.

\section{SELECTION OF EFFECTIVE CONCENTRATIONS:}

The metal exerts both promoting and retarding effect on the germination and seeding growth of the plant and it was essential to select a limited no. of concentration for further experiments. Thus five concentrations of $\mathrm{HgCl}_{2}(5,15,25,35, \& 45 \mathrm{mg} / \mathrm{L})$ were selected on the basis of LC 50 test. The data obtained from the germination and seedling growth experiments were used for screening.

\section{GERMINATION STUDIES}

The seeds of Vigna mungo L. PU 31 (urad bean) showed $90 \%$ germination. For germination studies sterilized Borosilicate glass petriplates were used. Petri dishes were sterilized in autoclave. Sterilized absorbent cotton and blotting papers were spread on the petriplates. Test chemical with distilled water was added to it. Seeds were soaked for $24 \mathrm{hrs}$ in the desired concentration of distilled water and test chemical, 10 numbers of seeds were sown in each petridish at uniform distance in all the sets. The blotting papers were made to wet at regular intervals with distilled water and respective concentration of the test chemical $(5,15,25,35$ $\& 45 \mathrm{mg} / \mathrm{L})$. The petridishes were incubated in the dark at room temperature (32 degree Celsius). The emergence of radicle or plumule was considered as an index of germination. Seeds were allowed to germinate. Better sprouted and healthy seedlings of 10 days old were used as experimental material. Care was taken to avoid drying and over flooding of test chemical in the petridishes.

\section{MORPHOLOGICAL STUDIES}

The growth of plant was evaluated by measuring the shoot and root length of seedlings on $10^{\text {th }}$ day.A $15 \mathrm{~cm}$ Scale was used for the measurement of the shoot and root length.

\section{FRESH WEIGHT AND DRY WEIGHT}

On $10^{\text {th }}$ day black gram seedlings were separated into shoots and roots. The fresh samples were kept in a hot oven at 80 degree Celsius for 30 minutes. After 30mins the dry weight of shoots and roots were taken by a digital balance.

\section{BIOCHEMICAL STUDIES}

Biochemical studies were made using 10 days old seedlings. For this purpose seedlings were grown as described before, the root and shoot portion of the 10 days old seedlings were separated, weighed and analysed for various biochemical components. 
Pigment content [6] Pigments and Phaeophytin [7] Amino Acids [8], Protein [9], Carbohydrates/Sugar [10] were estimated following standard quantitative methods.

\section{RESULTS \\ GERMINATION PERCENTAGE:}

The germination \% value of Black gram under $\mathrm{Hg} \quad \mathrm{Cl}_{2}$ treatment was recorded. The maximum germination was observed in control $(100 \%)$ With the increase in the concentration of the $\mathrm{Hg} \mathrm{Cl}_{2}$ percentage of germination decreased.

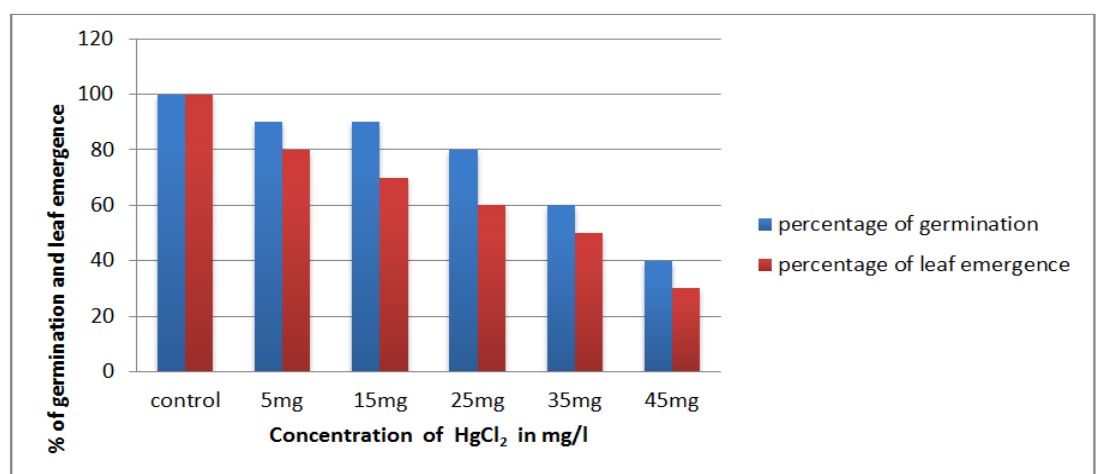

Fig--1: Effect of Mercuric Chloride stress on the of germination and leaf emergence of vigna mungo l.( 10 day old seedlings)

The result shows a reverse relationship between percentage of germination and concentration of mercury chloride i.e. the increase in concentration resulted in a decrease in germination percentage.

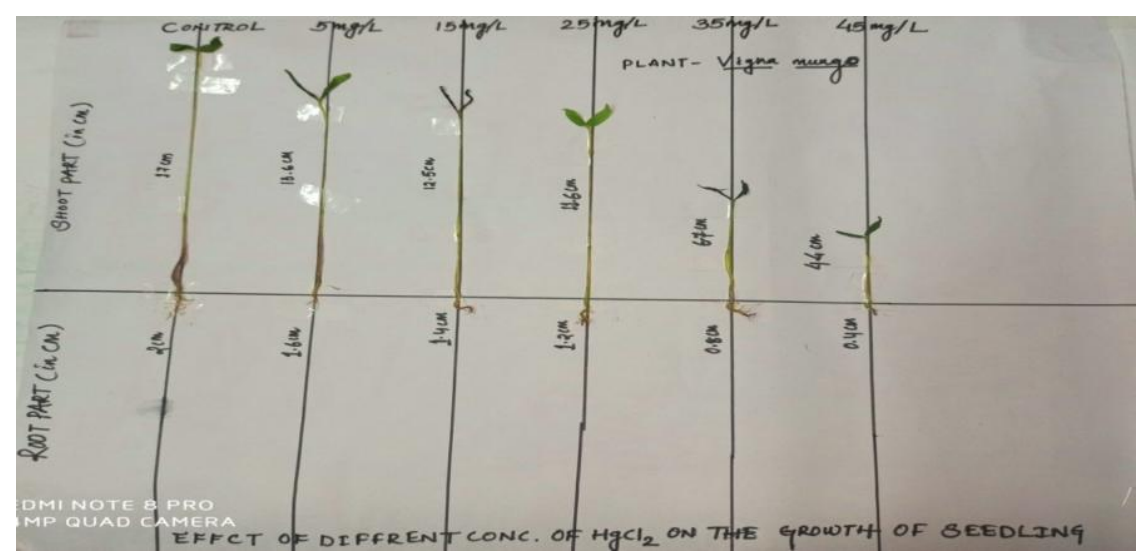

Fig-2

In shoot, there was a gradual decrease in the length as the concentration goes higher. In the 7 th day the shoot length of control was $17 \mathrm{~cm}$ where as the length in $45 \mathrm{mg} / \mathrm{l}$ concentration was only $4.6 \mathrm{~cm}$. The roots also exhibited same effects with increasing the concentration of Mercuric chloride. The control treatment was having the highest root length and the length decreased with increasing the Mercuric chloride concentrations.

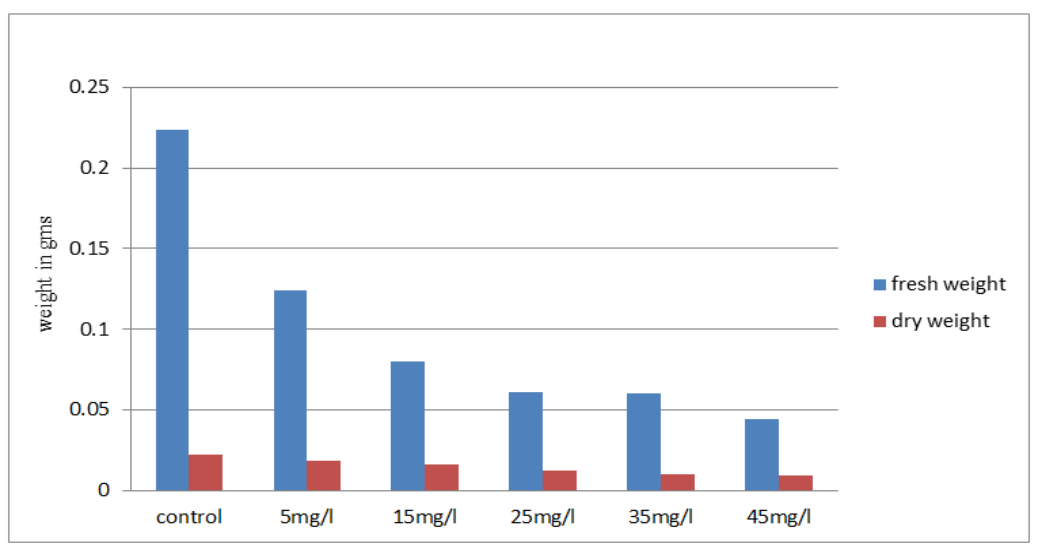

Fig-3: Effect of $\mathrm{HgCl}_{2}$ Stress on fresh weight \& dry weight of shoot of vigna mungo l. (10days old seedlings) 
Mamata Mohapatra et al., Sch Acad J Biosci, Mar, 2021; 9(3): 58-62

The fresh weight and dry weight of both shoot and root were maximum in control and least in the concentration of $45 \mathrm{mg} / \mathrm{l}$. Hence the respective weights decreased with increase in Mercuric chloride concentration.

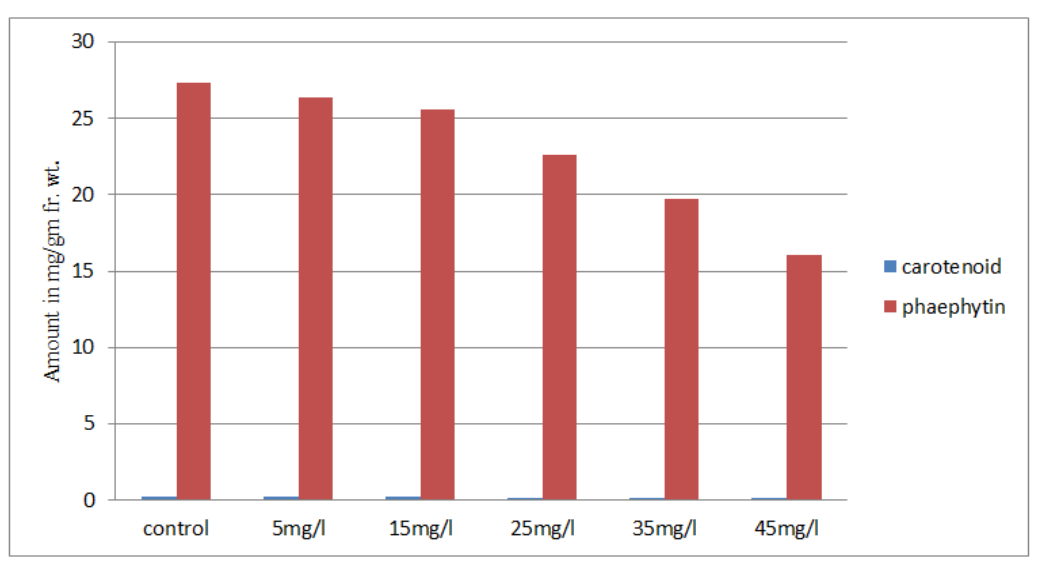

Fig-4: Effect of $\mathrm{HgCl}_{2}$ Stress on Caretenoid and Phaeophytin content of Vigna mungo. L. (10 days old seedlings)

The percentage of contents of carotenoids increased at $5 \mathrm{mg} / \mathrm{l}$ in concentration of Mercuric chloride and then decreased in other stress concentrations where as the contents of phaeophytin decreased gradually with increase in concentrations of Mercuric chloride.

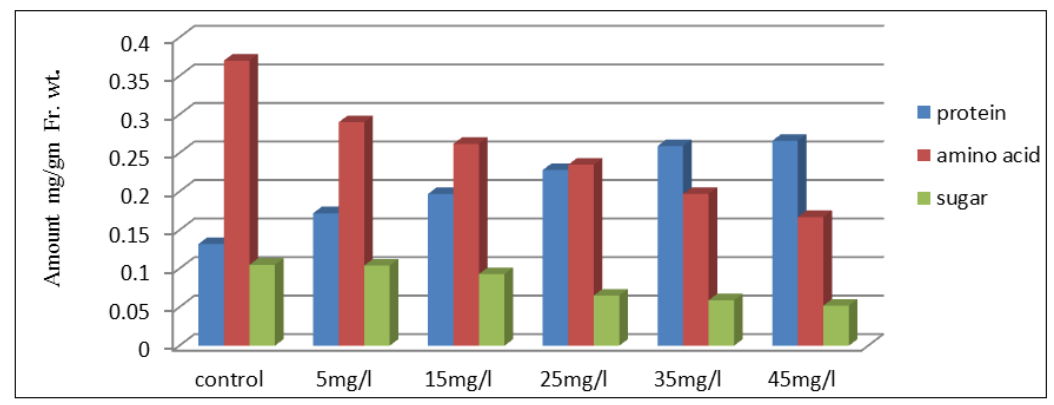

Fig-5: Effect of $\mathrm{Hg} \mathrm{Cl}_{2}$ Stress on Amino acid, Protein and Sugar contents in Shoot of Vigna Mungo.L. (10days old Seedlings)

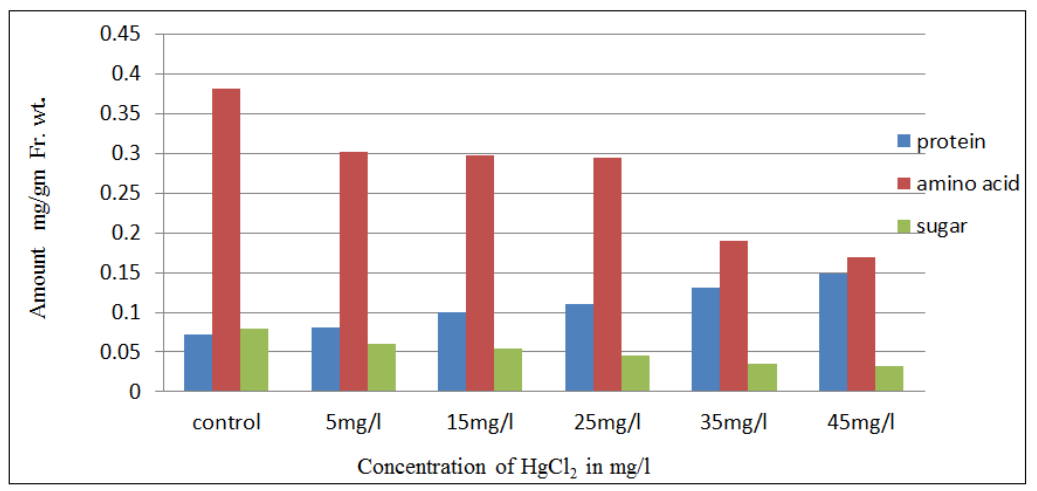

Fig-6: Effect of $\mathrm{HgCl}_{2}$ Stress on Protein, Amino Acids and Sugar of Root of Vigna mungo.L (10days old seedlings)

The contents of sugar and amino acid in both root and shoot are maximum in control treated seedlings (shoot and root) showed a decreasing trend in all parameters with the increase in concentration of Mercuric chloride. However, protein contents increased with the increase in Mercuric chloride concentrations

\section{DISCUSSION}

In the present study, Eco-physiological effects of Mercuric chloride was studied and different morphological and biochemical parameters were estimated by taking a local cultivated pulse crop Vigna mungo L. The results concluded that the presence of Mercury at higher concentration resulted in growth inhibition, structural change, a decline in physiological and biochemical activities which resulted in the disturbance in internal structure.

Mercury is considered highly toxic to the growth of plants. Chlorophyll biosynthesis is inhibited by heavy metals, particularly by inhibiting aminolevulinic acid dehydrogenase and 
protochlorophyllide reductase. This reduction might be due to interference of Mercury in pigment metabolism as reported. Plant growth and level of biomolecules in the cells and interfere with the activities of many key enzymes related to normal metabolic and developmental process. One of the clearest phytotoxic symptoms induced by heavy metals is a diminution in the plant growth, which is associated with disturbance of several metabolic processes, alteration of nutrient uptake and degeneration of cell ultra structure [11]. The fact that both mercury and cadmium cause the decrease in chlorophyll content in general provides support to the trend observed by earlier workers [12]. It can be concluded on the basis of experimental findings of the present study that, the higher concentration of mercury supplied to the plant results not only retarded germination and growth of the seedlings, but also it decreases the pigment content.

Essential elements at high concentrations and non- essential elements even at low concentrations are toxic $[2,13,14]$. Metals in the environment operate as stress factors causing physiological changes (strain) and in doing so reduce vigor, or in the extreme case cause death [15].

Heavy metals reduce the soluble protein in agricultural crops [16] as observed in this study. The decrease is caused either by a reduced de novo synthesis or by an increased decomposition of proteins to amino acids [17].

It is therefore essential to enhance the understanding the mechanism of Mercury uptake by plants and the various metabolic process that are targeted by this pollutant. This work could be a valuable source for other investigators to extend their research in this area of research.

\section{CONCLUSIONS}

The study conducted with mercury stress (in the form of mercury chloride) to 10 days old seedlings of mung (Vigna mungo,L.) showed stress condition in germination parameters and seedling physiology. The biochemical parameters also responded a declining trend in shoot and root of the seedlings with exception to protein content. Further experimental observations are to be carried out to find out the specific stress of mercury to seedlings.

\section{ACKNOWLEDGEMENTS}

Authors are thankful to Principal and HOD, Botany Department, Khallikote Autonomous College, Berhampur, Odisha, India for encouragement for project work and Laboratory facilities.

\section{BIBLIOGRAPHY}

1. Prasad MNV. Trace metals In: Plant ecophysiology. Wiley, New York, 1997; 263-273.

2. Mehera A, Farago, ME. Metal ions and plant nutrition. In: Farago ME. (ed) Plants and the chemical elements: biochemistry, uptake tolerance and toxicity, VCH. Weinheim, 1994;32-66,

3. Foy CD, Fleming AL. The physiology of plant tolerance to excess available aluminium and manganese in acid soils. Annual review of plant physiology. 1978;29:511-66.

4. Lenka M, Panda KK, Panda BB. Monitoring and assessment of mercury pollution in the vicinity of a chloralkali plant. IV. Bioconcentration of mercury in in situ aquatic and terrestrial plants at Ganjam, India. Archives of Environmental contamination and Toxicology. 1992 Feb;22(2):195-202.

5. Moore AW. Azolla: biology and Agronomic Significance, The Botanical Review, 1969, 35:17-34.

6. Arnon DJ. Chlorophyll absorption spectrum and quantitative determination. Bioch Bioph Acta. 1950;20:449-461.

7. Vernon LP. Spectrophotometric determination of chlorophylls and pheophytins in plant extracts. Analytical Chemistry. 1960 Aug 1;32(9):1144-50.

8. Lowry OH, Rosebrough NJ, Farr AL, Randall RJ. Protein measurement with the Folin phenol reagent. Journal of biological chemistry. 1951;193:265-75.

9. Moore S, Stein WH. Photometric nin-hydrin method for use in the ehromatography of amino acids. Journal of biological chemistry. 1948;176:367-88.

10. Yoshida S, Forno DA, Cock JH, Gomez KA. Laboratory manual for physiological studies on rice. Int Rice Res Inst Los Banes, Philippines, 1972.

11. Patra M, Sharma A. Mercury toxicity in plants. The Botanical Review. 2000;66(3):379-422.

12. Garg P, Tripathi RD, Rai UN, Sinha, S, Chandra P. Cadmium Accumulation and toxicity in submerged plant Hydrilla vertifillata (I.F) Royle. J of Env Monitoring and Assessmen. 1997;47:167-173.

13. Berry WL, Wallace A. Toxicity: the concept and relationship to the dose response curve. Journal of plant nutrition. 1981 Jan 1;3(1-4):13-9.

14. Baker AJ, Walker P. Physiological responses of plants to heavy metals and the quantification of tolerance and toxicity. Chemical Speciation \& Bioavailability. 1989 Mar 1;1(1):7-17.

15. Levitt J. Responses of Plants to Environmental Stresses.V.1. Chilling, freezing and high temperature stresses.-V.2. Water, Radiation, Salt and Other stresses. 2d.ed., 1980;212-265.

16. Hemalatha S, Anburaj A, Francis K. Effect of heavy metals on certain biochemical constituents and nitrate reductase activity in Oryza sativa L. seedlings. Journal of Environmental Biology. 1997;18(3):313-9.

17. Todd GW, Arnold WN. An evaluation of methods used to determine injury to plant leaves by air pollutants. Botanical Gazette. 1961 Dec 1;123(2):151-4. 